\title{
Knowledge Management in The Cloud Computing Model - Challenges, Opportunities and Risks
}

\author{
Artur Rot, Malgorzata Sobinska \\ Wroclaw University of Economics, \\ ul. Komandorska 118/120, \\ 53-345 Wroclaw, Poland \\ Email: \{artur.rot, \\ malgorzata.sobinska\}@ue.wroc.pl\}
}

\begin{abstract}
With the increasing globalisation, the models for running business are changing as well, thus increasing the need for innovative knowledge management. This is facilitated by the development of information and communication technologies, which are the basis of numerous innovative solutions in the field of knowledge management. This article draws attention to the current trend in the area of IT management associated with the emergence and greater use of cloud computing. The article is an attempt to assess the impact of cloud computing on the key areas of knowledge management. It presents the challenges faced by organisations which place the emphasis on improving their competitive position, the possible positive consequences of the implementation of cloud solutions, as well as risks stemming from the use of clouds in the context of knowledge management.
\end{abstract}

\section{INTRODUCTION}

$\mathrm{T}$ HE organisations that want to meet the emerging requirements and challenges of the market need to manage knowledge with particular skill, whereas the management should be tailored to individual needs and capabilities, as well as strategic objectives of the company. Knowledge management strategy should be based on three fundamental pillars: people, technology and processes [5]. Its implementation requires the integration of knowledge management processes with the strategic objectives of the organisation and business processes, operations in the social dimension - concerning the values and good practices cultivated in this area, and the provision of tools (modern technologies) necessary for the effective management of resources and knowledge processes. The experience of companies shows that success in knowledge management is achieved by the organisations which skillfully combine activities in each of these areas. Mere possession of knowledge and experience does not guarantee high efficiency.

In the article, the attention will be focused on the third dimension, i.e. the technology, which - despite not being the only or even the most important part of knowledge management - is nowadays a prerequisite for the successful functioning of the company in the reality of global competition.

Organisations based on knowledge must create very specific and sophisticated information environment where information processes run using the most advanced information technology, covering both hardware and software [4, p. 15]. Companies are not always able to meet these challenges alone, therefore they frequently use external knowledge sources and external IT resources, resorting to, among others, various technologies for efficient functioning on a competitive market.

A study conducted on a group of companies operating in Poland shows that companies use various forms of sourcing for IT services. As many as $91 \%$ of the respondents admitted to the use of IT outsourcing, while $26 \%$ use cloud computing, and $13 \%$ prefers offshoring services [13]. The popularity of the use of cloud computing is also confirmed by research conducted among providers of cloud computing, system integrators, and users of cloud services [15, p. 279]. Other studies conducted by Cloud Connect and Everest Group from 2014 carried out on a group of 214 companies from around the world have shown that most organisations treat cloud computing as a strategic differentiator enabling operational excellence and accelerated innovation, in other words, they recognise the proposed value of the implementation of cloud solutions [12].

The main aim of this article is to attempt to assess the possible impact of cloud computing on the key areas of knowledge management. It will focus on both the potential positive and negative effects of the implementation of cloud solutions and the conditions under which the use of the cloud is worth considering.

The article is based on the analysis of literature and the results of the author's own empirical research involving interviews with employees of the IT departments in randomly selected organisations. 


\section{CHALlENGES FOR KNOWLEDGE MANAGEMENT IN MODERN ORGANISATIONS}

The practice of knowledge management, whose importance was first recognised by leading organisations over twenty years ago, is now regarded as an integral part of management in almost every business organisation. The use of knowledge management processes increases the efficiency of decision-making processes as well as the level of operational efficiency, flexibility and the involvement of employees.

Globalisation is forcing organisations to adopt new styles of conducting business. Extended supply chains require more coordination through measures such as management of relationships with suppliers, management of internal processes, and management of customer relationships. Effective management of these elements requires significant changes in business strategies and encourages the use of new technologies [6]. The constant development of technology, in turn, causes the processes in enterprises to become more complicated, due to which the company is not always able to satisfy the requirements associated with owning, acquiring and developing the appropriate resources, including skills, knowledge and qualifications.

Increasingly, enterprises establish cooperation on the basis of various types of relationships, alliances, relationships, joint network-based forms of cooperation (e.g. logistic networks and production networks). There is a change in the location of knowledge and core competencies, which shift to the network, which in turn affects the changes in relation to innovation as a process based on competence. The novelty is the participation of consumers in the process of innovation and the use of their personal experience with the use of products or services as a rich source of ideas, which happens thanks to the highly-developed information technologies. From the position of the creator of innovation, the company moves to the position of the executor of the created innovation together with the consumer (e.g. through crowdsourcing), or partner - for example through cloud computing [11 p.17-19].

\section{SERVICES OF KNOWLEDGE MANAGEMENT IN THE CLOUD}

Cloud computing has great potential to provide knowledge management services in the following areas: improving decision-making processes, improving profitability, reducing the response time for critical problems of growth: productivity, market share, share prices, and competitive advantage.

Three basic models of cloud computing: IaaS Infrastructure as a Service, PaaS- Platform as a Service and SaaS - Software as a Service can help organisations develop new models of knowledge management, collaborate with other organisations and facilitate the exchange of knowledge [1]. Cloud computing, according to M. Rafiq et al. not only provides an excellent location to manage data, information and knowledge, but also provides a platform that can be used to make them available on demand, as well as other resources (networks, servers, storage, applications and services). Among the benefits of the integration of cloud computing with the system for knowledge management, there are: cost reduction, adaptation of new practices, discovery of new business models, and providing knowledge as a service (KaaS - Knowledge as a Service) [6]. S. Khoshnevis and F. Rabeifar propose the use of cloud technology to provide knowledge management, which can be widely used within the framework of business intelligence and competitive intelligence. Currently, these possibilities are not used for intra- and inter-organisational knowledge management systems. The authors illustrate the architecture of KMaaS (Knowledge Management as a Service) along with detailed services and associations and the relations between them. They also analyse how different cloud models can be used for knowledge management in the cloud environment and predict their application scenarios [3].

From the viewpoint of the "cloud's" availability, it can be divided into the following categories [11, p.98]:

- private (internal);

- common (social);

- public;

- hybrid.

S. Khoshnevis and F. Rabeifar examine the relationship between the use of these models and the access to knowledge (explicit and quiet/hidden). Table 1 presents this relationship by referring the access to a specific type of knowledge for each of the cloud models.

TABLE I.

ACCESS TO KNOWLEDGE IN VARIOUS CLOUD MODELS

\begin{tabular}{|l|l|l}
\hline \multicolumn{1}{|c|}{ Type of cloud } & \multicolumn{1}{c|}{$\begin{array}{c}\text { Explicit } \\
\text { knowledge }\end{array}$} & \multicolumn{1}{c}{$\begin{array}{c}\text { Hidden/quiet } \\
\text { knowledge }\end{array}$} \\
\hline Private cloud & Local/limited & Local/very limited \\
\hline Public cloud & Very big & Extremely big \\
\hline $\begin{array}{l}\text { Social (common) } \\
\text { cloud }\end{array}$ & Shared/limited & Shared/unlimited \\
\hline
\end{tabular}

In the case of private cloud, the access to explicit and hidden knowledge is local and limited to the organisation that owns the cloud. The launch of KMaaS in a private cloud seems to have a minimal impact on the knowledge management system, as it practically coincides with the local system of knowledge management. By contrast, the implementation of $\mathrm{KMaaS}$ in a public cloud looks very different. In this case, there is a high level of access to knowledge, both explicit and hidden, and it is particularly high in relation to the hidden knowledge, as it naturally belongs to a larger number of users (human minds) which use public cloud resources.

Social clouds are shared between specific organisations. In the case of access to the explicit and hidden knowledge, the access is neither as limited as in a private cloud, nor as 
wide and open as in a public cloud. Hidden knowledge in this model is more readily available for the same reasons as the ones mentioned above with respect to a public cloud. The level of access to knowledge in hybrid solutions is difficult to investigate and depends on a combination of clouds hosted by the hybrid cloud.

Another point of the analysis pertains to the access to domain knowledge, depending on the location of the cloud whether the cloud is owned by the organisation (whether it is "inside" the organisation) or is located on the "territory" of another organisation (outside) (Table 2).

TABLE II

ACCESS TO DOMAIN KNOWLEDGE IN VARIOUS CLOUD MODELS

\begin{tabular}{|l|l|l}
\hline Type of cloud & \multicolumn{1}{|c|}{ "Inside" area } & \multicolumn{1}{c}{ “Outside" area } \\
\hline Private cloud & $\begin{array}{l}\text { limited/local } \\
\text { organisational } \\
\text { knowledge }\end{array}$ & Inaccessible \\
\hline Public cloud & $\begin{array}{l}\text { limited/local } \\
\text { organisational and } \\
\text { technological } \\
\text { knowledge }\end{array}$ & $\begin{array}{l}\text { unlimited inter- } \\
\text { organisational external } \\
\text { organisational/technolo } \\
\text { gical/marketing } \\
\text { knowledge }\end{array}$ \\
\hline $\begin{array}{l}\text { Social } \\
\text { common) } \\
\text { cloud }\end{array}$ & $\begin{array}{l}\text { limited/local } \\
\text { organisational and } \\
\text { technological } \\
\text { knowledge }\end{array}$ & $\begin{array}{l}\text { limited inter- } \\
\text { organisational external } \\
\text { organisational/technolo } \\
\text { gical/marketing } \\
\text { knowledge }\end{array}$ \\
\hline Hybrid cloud & $\begin{array}{l}\text { limited/local } \\
\text { organisational and } \\
\text { technological } \\
\text { knowledge }\end{array}$ & $\begin{array}{l}\text { limited/unlimited inter- } \\
\text { organisational external } \\
\text { organisational/technolo } \\
\text { gical knowledge }\end{array}$ \\
\hline
\end{tabular}

Private clouds offer limited local organisational knowledge, but do not give access to external knowledge. External clouds provide cross-organisational knowledge from all three areas (organisation, marketing, technology), while private clouds provide local intra-organisational knowledge. Public clouds provide unlimited access to knowledge, whereas social clouds provide limited access to knowledge, as well as hybrid clouds, which do not always provide permanent access to knowledge. Moreover, internal clouds (public and hybrid) can provide limited access to a maximum of two areas of expertise: organisational and technological [3].

The third point of the analysis refers to the degree of access to knowledge (explicit/hidden) in different cloud models. The level of access to both kinds of knowledge is low when using the private cloud. Public clouds allow wider access to knowledge, while the range of hidden knowledge is greater. Social clouds predict low or medium level of access to the two types of knowledge, whereas it is more difficult to analyse the level of access for hybrid clouds, which are a combination of all other types of clouds - they are usually estimated at the secondary level (Table 3).

Knowledge management can use cloud computing in two ways. Firstly, thanks to cloud computing, it adapts to
TABLE III.

ACCESS TO KNOWLEDGE IN VARIOUS CLOUD MODELS

\begin{tabular}{|l|l|l}
\hline \multicolumn{1}{|c|}{ Type of cloud } & Explicit knowledge & Hidden knowledge \\
\hline Private cloud & low & low \\
\hline Public cloud & high/medium & high \\
\hline $\begin{array}{l}\text { Social (common) } \\
\text { cloud }\end{array}$ & medium/low & medium \\
\hline Hybrid cloud & medium (mixed) & medium (mixed) \\
\hline
\end{tabular}

technological advances, and secondly, it has the means which facilitate the exchange and acquisition of knowledge in a highly scattered and dynamic environment. Internet technology gives the possibility to build sophisticated, well performing knowledge management system designed to deliver content, from multiple sources, to each individual, in the individual's specific context and under the individual's own control. This ability helps to improve the relationship between knowledge/information/data suppliers and consumers by providing both parties more precise control over the interaction. Cloud technologies allow for a certain kind of controlled relationships between public, private, social, and hybrid clouds. In such a space, there is a facilitated creation of modern, network and virtual business models, which on the one hand require constant access to knowledge, and on the other hand supply and share vast amounts of valuable knowledge by themselves, which generates the need for a controlled exchange of knowledge between them.

\section{The Potential AND Risks OF ClOUd COMPUTING IN THE CONTEXT OF KNOWLEDGE MANAGEMENT}

Organisations would like to benefit from the benefits of a "cloud" tailored to their needs, and the choice of a specific type is usually dictated by the size of the organisation, the scale of its activities, the willingness to take risks, and the investment opportunities [11, p. 99].

The benefits of a "cloud" are, among others: scalability, high availability, high performance, reliability, simplified management, flexibility. Thanks to these characteristics, cloud solutions can be regarded as a kind of accelerator for changes in the IT area, but like any new technology, they carry some risks [7].

According to IDC report, the market of data processing in cloud computing is currently the fastest growing part of the Polish market of information exchange [2]. Rapidly changing modern technologies offer great advantages, but, unfortunately, they also bring with them new forms of risk, making the traditional approach to information system security inadequate to the present situation. There constantly arise new types of risks, often misunderstood and underestimated by the management of the organisation [9]. The main risks, similarly as in the case of the classic outsourcing of IT services, include: loss of control over the 
TABLE IV.

THE BENEFITS AND RISKS OF IMPLEMENTATION OF CLOUD COMPUTING IN SELECTED AREAS OF KNOWLEDGE MANAGEMENT, OWN WORK

\begin{tabular}{|c|c|c|}
\hline $\begin{array}{c}\text { Areas/objectives of } \\
\text { knowledge } \\
\text { management }\end{array}$ & The potential of cloud computing & The risk associated with the implementation \\
\hline $\begin{array}{l}\text { Strategy/development of } \\
\text { knowledge and } \\
\text { competence resources }\end{array}$ & $\begin{array}{l}\text { Access to external expertise, the latest technology; } \\
\text { providing tools to enable access to organisational and } \\
\text { technological knowledge; providing tools for support of the } \\
\text { transfer and sharing of knowledge. }\end{array}$ & $\begin{array}{l}\text { Loss of control over the IT environment; } \\
\text { Dependence on the suppliers of cloud services. }\end{array}$ \\
\hline $\begin{array}{l}\text { Human resources } \\
\text { management/ } \\
\text { development of } \\
\text { intellectual capital }\end{array}$ & $\begin{array}{l}\text { Relieving the staff of the technical aspects and focusing on } \\
\text { the core business activity; } \\
\text { Developing new skills and competences in the field of IT; } \\
\text { Improved cooperation and transfer of knowledge between } \\
\text { organisations. }\end{array}$ & $\begin{array}{l}\text { Possible loss of intellectual capital in case of the } \\
\text { dismissal of IT staff as a result of the adaptation } \\
\text { of cloud solutions; } \\
\text { The loss of the capacity needed to return to self- } \\
\text { provided IT services. }\end{array}$ \\
\hline Process management & $\begin{array}{l}\text { Supporting innovation; } \\
\text { Reducing the time of process implementation. }\end{array}$ & \\
\hline $\begin{array}{l}\text { Marketing/business } \\
\text { intelligence/innovation }\end{array}$ & $\begin{array}{l}\text { Possibly unlimited access to internal and external } \\
\text { knowledge. } \\
\text { Ensuring the possibility of direct integration of external } \\
\text { entities with the company; } \\
\text { Supporting market-driven innovation (for } \\
\text { products/services). }\end{array}$ & $\begin{array}{l}\text { The possibility of losing competitive advantage } \\
\text { by acquiring strategic information or sensitive } \\
\text { data by the competitors. }\end{array}$ \\
\hline $\begin{array}{l}\text { Information } \\
\text { technology/Information } \\
\text { security management }\end{array}$ & $\begin{array}{l}\text { Improved use of IT resources, high scalability of IT } \\
\text { resources, availability, performance and reliability; } \\
\text { Easier management, greater flexibility of IT infrastructure; } \\
\text { Increased security thanks to advanced data protection tools } \\
\text { used by service providers. }\end{array}$ & $\begin{array}{l}\text { Loss of control over the IT environment; } \\
\text { System failures; } \\
\text { Services unfit for the actual needs of the } \\
\text { organization; } \\
\text { The decrease in safety (in the case of suppliers } \\
\text { having weaker security systems); } \\
\text { The possibility of loss and/or unauthorised use } \\
\text { of sensitive data. }\end{array}$ \\
\hline
\end{tabular}

IT environment, failure of the mechanisms separating multitenants, risk of the loss of regulatory compatibility, insufficient data protection, the possibility of dependence on suppliers and the inability to return to self-provided IT services [8].

Table 4 presents the key risks and opportunities of cloud computing in respect of the areas and objectives of the "classic" knowledge management.

Proper management of the relationship with the cloud service provider can minimise some of the risks [9]; it also allows to standardise the variable IT environment in the cloud, reduction of operating costs and the achievement of comprehensive business knowledge. However, it requires a strong commitment on the part of managers, who must be capable of error-free evaluation of the current potential of IT, and anticipate the needs in order to not only take advantage of current opportunities, but also those that will appear in the next few years in the context of cloud computing. Cloud computing is in fact a platform for six other technologies, the combination of which, as experts predict, will have a huge impact on the future operation of the enterprises. They are as follows [14]: processing associated with the mobile Internet, automation of knowledge-based works, robotics, Big Data, Internet of Things (IoT), and production based on 3D technology.

In the face of such an accelerated technology development, maintaining technological capacity within the organisation is critical, among other things, as a basis for the use of constantly growing outsourced IT and cloud computing services. It is also necessary to carry out technological changes in the organisational context in order to achieve a substantial and sustainable competitive advantage.

\section{V.CONCLUSION}

This article will serve as a starting point for more detailed research and analysis both in the purely technological area (e.g. regarding the mechanisms associated with the acquisition, processing or distribution of information; information security, etc.), and the "soft" area - e.g. a study of the impact of the adoption of cloud solutions for: managing the IT area, shaping the relationship between business departments, project management etc.

To sum up the above-mentioned considerations, one can come to the following conclusions:

- Proper management and transfer of knowledge within the organisationnd in the relationship with the environment, 
which is conducive to the development of IT, is vital to the survival and development of the organisation;

- Cloud computing can be a tool to support knowledge management and thus facilitate the growth of the efficiency of the IT departments and other units. It can become a valuable tool for access to and sharing of knowledge in the inner space of the organisation and in relations with other actors;

- Cloud computing can affect innovation services, processes, and even create new business models, and thus contribute to the improvement of the competitive position of companies that will adopt it skillfully.

In the complex and turbulent economic conditions, it is impossible to efficiently and effectively implement knowledge management processes without adequate support from increasingly advanced technology. In a situation where competition forces organisations to race against time, only the use of appropriate technological tools can improve (and sometimes even allow) the implementation of certain processes in the area of knowledge management [5].

It is, however, important to note that IT is only one of the three pillars of knowledge management. Today, information technologies are a prerequisite for the functioning of companies on global, highly competitive markets, but they cannot become the sole focus of knowledge management.

\section{REFERENCES}

[1] Afshari M., "Cloud-Based Knowledge Management", 2016, http://cloudtweaks.com/2014/06/cloud-based-knowledgemanagement/, (accessed: 28.04.2016).

[2] IDC, "Polski rynek uslug w chmurze wzrosnie o 25 proc. w 2015 r", Puls Biznesu http://www.pb.pl/4275592,70326,idc-polski-rynekuslug-w-chmurze-wzrosnie-o-25-proc-w-2015-r, (accessed: 12.09.2016).

[3] Khoshnevis S., Rabeifar F., "Toward Knowledge Management as a Service in Cloud-Based Environments, International Journal of Mechatronics", Electrical and Computer Technology, Vol. 2(4), July 2012, pp 88-110, ISSN: 2305-0543, http://www.aeuso.org (accessed: 26.04.2016).
[4] Kozminski A. K., "Wstep", D. Jemielniak, A.K. Kozminski (eds.), Zarzadzanie wiedza, Wydawnictwa Akademickie i Profesjonalne, Warsaw, 2008, pp. 7-16.

[5] Mierzejewska B., "Czym (nie) jest zarzadzanie wiedza", E-mentor 1 (3) / 2004, pp. 37-39.

[6] Rafiq M., Bashar A., Shaikh A., "Innovative Trends in Knowledge Management: A Cloud Computing Perspective", Proceedings of the First Middle East Conference on Global Business, Economics, Finance and Banking (ME14 DUBAI Conference) 2014, http://globalbizresearch.org/Dubai_Conference/Conference_Papers.ph p, (accessed: 26.04.2016).

[7] Rot A., "Enterprise Information Technology Security: Risk Management Perspective", Proceedings of the World Congress on Engineering and Computer Science 2009, Vol II, 2009, pp. 11711176.

[8] Rot, A., Sobinska, M., "IT security threats in cloud computing sourcing model”, M. Ganzha, L. Maciaszek, M. Paprzycki (eds.) Proceedings of the 2013 Federated Conference on Computer Science and Information, PTI, Cracow, https://fedcsis.org/proceedings/2013/pliks/fedcsis.pdf (accessed: 28.10.2016).

[9] Rot A., „Zarzadzanie ryzykiem w cyberprzestrzeni - wybrane zagadnienia teorii i praktyki”, T.M. Komorowski, J. Swacha (eds.), Projektowanie $i$ realizacja systemow informatycznych zarzadzania. Wybrane aspekty, Polskie Towarzystwo Informatyczne PTI, Warsaw 2016.

[10] Sobinska M., "Sourcing uslug i procesow informatycznych jako czynnik wzrostu innowacyjnosci organizacji”, Management Science 4(21)/2014, ISSN 2080-6000, Wroclaw University of Economics Publishing House, Wroclaw, pp. 75-85.

[11] Sobinska M., Przewodnik sourcingu IT, Wroclaw University of Economics Publishing House, Wroclaw 2015.

[12] Sobinska M., Butryn B., „Cloud computing a transformacja roli dzialow IT", Przeglad Organizacji 8(907)/2015, TNOiK journal, pp.32-38.

[13] Sobinska M., Willcocks L.P., "IT outsourcing management in Poland - trends and performance", Strategic Outsourcing: An International Journal, Vol. 9/2015 Issue No. 1, http://www.emeraldinsight.com/doi/full/10.1108/SO-10-2015-0024 (accessed: 19.09.2016).

[14] Willcocks L., "How are we doing on cloud? Nine insights from leading global organizations", Professional Outsourcing Resources, 2016, http://www.professionaloutsourcingmagazine.net/insight/howare-we-doing-on-cloud-nine-insights-from-leading-globalorganizations, (accessed: 8.04.2016).

[15] Willcocks, L. P., Lacity M. C, 2012, "The new IT outsourcing landscape. From innovation to cloud services", Palgrave Macmillan. 